\title{
THE EFFECT OF PERCEIVED THREAT ON HYPERTENSION PREVENTIVE BEHAVIOR IN KUPANG, EAST NUSA TENGGARA
}

\author{
Rafael Paun'), Chatarina UW', Hari Basuki'2), Rhamat Hargono' ${ }^{2)}$ \\ ${ }^{1)}$ School of Health Polytechnics, Ministry of Health, Kupang, East Nusa Tenggara \\ ${ }^{2)}$ Faculty of Public Health, Airlangga University, Surabaya, East Java
}

\begin{abstract}
Background: The prevalence of hypertension has increased annually in Kupang, East Nusa Tenggara. Hypertension is hypothesized to be influenced by behavior and lifestyle. This study aimed to determine the effect of perceived threat on hypertension preventive behavior, using health belief model.

Subjects and Method: This was an analytic observational study with a crosssectional design. This study was conducted in Kupang, East Nusa Tenggara. A sample of 180 study subjects was selected for this study by multistage random sampling. The dependent variable was hypertension preventive behavior. The independent variable was perceived threat. The data were measured by questionnaire and analyzed by path analysis.

Results: Hypertension preventive behavior increased with stronger perceived threat $(b=4.07 ; p=0.084)$.

Conclusion: Hypertension preventive behavior increases with stronger perceived threat.
\end{abstract}

Keywords: hypertension, preventive behavior, perceived threat

Correspondence:

Rafael Paun. School of Health Polytechnics, Ministry of Health, Kupang. 